UDC 551.4.013: 911.52

\title{
ANALYSIS OF RELIEF MORPHOLOGY OF UKRAINIAN CARPATHIANS THROUGH THE METHOD OF AUTOCOVARIOGRAMS
}

\author{
Oleksandr Mkrtchian
}

\author{
Ivan Franko National University of Lviv, \\ Doroshenko Str., 41, UA - 79000 Lviv, Ukraine \\ alemkrt@gmail.com
}

\begin{abstract}
Quantitative morphometric relief analysis is a fast-growing research area concentrating on a set of important tasks. One of these is the quantitative characterization of relief forms and types that would allow to build their morphometric signatures and distinguish them objectively and automatically. This task can be accomplished by the analysis of autocovariance/autocorrelation structure of the surface.

The task of present research has been to calculate the autocovariograms for terrain surfaces for five tectonic and geological zones of Ukrainian Carpathians and to analyze their general form using $\mathrm{R}$ script specially written for the task. This script takes as an input the digital elevation model (SRTM Version 4.1 DEM) cut for every zone, and outputs the table with two fields that keep the values of distances (lags) and corresponding autocovariances. This table in its turn can be depicted as a graph - autocovariogram, with plotting capabilities of R.

While each of the five obtained autocovariogram looks similar, their closer analysis reveals some significant differences in detail. Generally, autocovariograms differ in their initial values, the presence of the detectable periodicity in terrain (indicated by pronounced local minimum in autocovariogram), and the range distance at which they approach 0 . In general, features and parameters of autocovariogram can be indicative of tectonic structure and processes, the genesis and composition of rocks, and the dominant morphodynamic processes.

Key words: geomorphometry, autocovariogram, R, digital elevation model, Ukrainian Carpathians.
\end{abstract}

Quantitative research methods and techniques are the hallmark of modern scientific methodology, making research results reproducible and more reliable. However, studies in Earth sciences still mostly rely on qualitative methods, producing descriptive results that are hard to reproduce and to transform into the form readily understandable to practitioners and to researchers from other scientists fields. The studies of Earth relief are no exception. Whereas Ukrainian geomorphologists and other Earth scientists not always command enough skills to apply modern quantitative research methods, particularly involving software creation and manipulation, in their everyday research work, they have accumulated a lot of valuable regional and local knowledge.The latter could be of interest not only for their colleagues and practitioners in their own country, but also for scientists abroad as a valuable empirical contribution to the scientific knowledge in the field of geomorphology.

Among the different relief characteristics (its genesis, age, dynamics, morphology), morphometric characteristics are those that most readily lend themselves to quantitative analysis. The real boost in the quantitative morphometric analysis came with the advent of Digital elevation models (DEM) and modern computer techniques

(C) Mkrtchian O., 2018 
of their processing. Starting from the late 1980-th, conceptual works have emerged that formulate the theoretical basis and the main tasks and topics of geomorphometry as the study of the quantitative analysis of Earth landforms [10, 11]. These topics included the search for objective and reproducible methods for classification of landforms and relief types, automatic delineation of drainage channels and networks, quantitative analysis of geomorphic and hydrologic processes dependent on the shape of land surface (soil erosion,landslide and avalanche development, groundwater movement), the morphometric detection of hazardous processes (landfalls, landslides, subsidence of land, avalanche tracks) [9, 10, 11, 12]. Quantitative relief analysis has also been applied in other areas of Earth sciences dealing with the impact of terrain on climate, soils, ecological conditions, etc. Terrain characteristics, like altitude (local as well as non-local), regional aspect, dissectedness - can be used as predictive variables to model the distribution of temperature and precipitation fields, thus allowing to interpolate the point data determined instrumentally at weather stations $[6,8]$. Terrain attributes can also be used to interpolate and predict the distribution of soil properties and attributes, as they are influenced by the gravitationally controlled water and substance movement processes [9]. And as ecosystems characteristics are dependent on ecological factors related to properties of soil, local climate, water and nutrients movements that in their turn are controlled by terrain, the properties of the latter can in effect serve as indirect ecologic gradients [3], and can be used as such in predictive vegetation mapping $[2,3,7]$.

During last decades geomorphometry has shaped itself into the mature research field. International conferences on geomorphometry have been held in 2009 (Zurich, Switzerland), 2011 (Redlands, California, USA), 2013 (Nanjing, China), 2015 (Poznan, Poland), and 2018 (Denver, USA). After each one, Proceedings volumes have been issued, freely downloadable online. International Society for Geomorphometry (ISG) has been established as an international association of researchers and experts open for free exchange of knowledge and opinions about various aspects of DEM processing and digital relief analysis.http://geomorphometry.org/

There are several main directions of research in theoretical geomorphometry. One is aimed at substantiating the set of terrain morphometric attributes (parameters) that collectively exhaustively describe terrain form in every location. P. Shary has proposed a set of morphometric variables as quantitative terrain characteristics based on the mathematical description of continuous land surface [12]. From 18 variables proposed by him, most are different types of land surface curvature. These variables are divided into two groups: field-specific (characterizing the interaction of land surface with a vector field, generally - the gravitation one), and those that ignore these fields. Based on combinations of these variables, P. Shary has distinguished 12 simple morphometric terrain forms [12].

Another related task of modern geomorphometry consists in the development of automatic methods of objective and reproducible distinguishing and delineation of terrain forms, types and the manifestations of geomorphic processes. These methods are based on the concept of geometric signature - the specific combination of the values of morphometric variables that allow to uniquely identify an object or group thereof [1].

While the most of morphometric variables characterize the form of land surface in certain location or its vicinity, the methods are of interest that could characterize the 
geometry and structure of the entire land surface belonging to a certain genetic terrain type, tectonic unit, geological formation, etc. If it is possible to derive a specific morphometric signature of a certain unit, then this signature could be applied to automatically distinguish the same kind of units in other places.

The prospective method to characterize the geometry of a certain part of continuous surface is based on the analysis of autocovariance/autocorrelation structure of the surface. Spatial autocorrelation is a measure of dependency among observations in a geographic space. The concept of spatial autocorrelation is more complex than that of one-dimensional autocorrelation (e.g., in time series) because it deals with two- or three-dimensional data. There are some special measures (statistics) that characterize the level of spatial autocorrelation in data, the most common of which are Moran's I and Geary's C. Yet, they characterize autocorrelation as a global distance-independent property, describing it with a single value. However, autocorrelation can also be calculated with variable spatial lags, thus characterizing an inherent spatial variability and periodicity in data. The graphs showing autocorrelation or autocovariance as a function of lag, are called autocorrelograms or autocovariograms.

As a rule, autocorrelation andautocovariance are the highest for the smallest lags (corresponding to close locations) and then monotonously decrease with increase in lag - a manifestation of "Tobler's first law of geography" $[13,14]$.Still, the concrete shape of these curves will be different in any single case and will characterize the peculiar properties of the spatial structure of the surface.

The shape of these graphs calculated on topographic surfaces are indicative of relief type and can be regarded as a kind of morphometric signature. For example, if the terrain surface consists of homogeneous parts (blocks) of a certain characteristic size with sharp transitions between them, the autocovariogramwill show high values for the small lags, than a sharp decrease in value when lags become larger than the size of these parts. When the surface is characterized by periodicity (e.g., with a set of parallel mountain ridges divided by narrow valleys), autocovarianceand autocorrelation will be very small or negative for the lags corresponding to typical distances between opposite relief forms (neighboring ridge tops and valley bottoms) and then, contrary to general tendency, will increase with lag as the latter approaches the typical distances between similar relief forms (two neighboring ridge tops or neighboring valley bottoms).

The aim of our research has been to calculate the autocovariograms for terrain surfaces for several tectonic subdivisions of Ukrainian Carpathians, to analyze the general form of these autocovariograms and to study relationships between this form and the genetic and morphological features of theses subdivisions.

Carpathians are one of the largest mountain ranges in Europe, providing an essential habitat and refuge for many endangered species of plants and animals and Europe's largest area of virgin forests, and constituting a major economic, cultural, recreational and living environment in the heart of Europe, shared by numerous peoples and countries. Ukraine hosts the north-eastern part of Carpathian arc, where it is the narrowest $(\sim 100 \mathrm{~km})$ and connects more wide and monolithic parts of Eastern and Southern Carpathians (inside Romania) and Western Carpathians (in Slovakia and Poland). Carpathians are the largest and highest mountain range in Ukraine, hosting the large part of country's biodiversity, as well as providing indispensable ecosystem services and being an important area for local and regional tourism and recreation. 
Ukrainian Carpathians were formed during the Alpine orogeny in the Mesozoic and Tertiary as a fold and thrust belt with northeast vergence.Most of them constitute the Carpathian Flysch Belt - a thrust belt (accretionary wedge) made of several rootles nappes consisting of so-called flysch- alternating Cretaceous to Paleogene marine deposits of claystones, shales and sandstones which were detached off the sea bottom and thrust over the North-European plate tens of kilometers to the north. To the south of it lie Neogene volcanic complexes and Marmaros crystal massif made up of hard igneous rocks.

The study area of our research comprises most of the Carpathian mountains inside the borders of Ukraine, with the total area $20179 \mathrm{~km}^{2}$. While there are several schemes of the regionalization of Ukrainian Carpathians relief and landscapes, they generally agree on delineation of the several structural-facial zones, that run longitudinally along the axis of Carpathian arch and are divided from one another by regional thrusts.

For the aim of this research, the total study area was subdivided into five large zones mainly by criteria of general tectonic and geological structure. The important consideration has been the area of each zone which is large enough to calculate the autocovariogram of its elevation values. The list of these zones and their location is given in Fig. 1.

The source of elevation data has been the SRTM Version 4.1 DEM [4] with spatial resolution of $\sim 70 \mathrm{~m}$. DEM tiles were downloaded from USGS EarthExplorer web site https://earthexplorer.usgs.gov/, then merged into one raster, reprojected into UTM 34N coordinate system and lastly cut to the boundaries of study region. Then the obtained DEM of $20179 \mathrm{~km} 2$ area has been overlaid with the vector layer of boundaries of abovementioned structural zones and cut-masked into five parts. Each "partial" DEM is thus reflecting the terrain structure of the corresponding zone (Fig. 1).

To calculate the autocovariograms, the script has been written in $\mathrm{R}$ language to analyze how the autocovariance of values of the elevation grid change with the distance lag. $\mathrm{R}$ is a free software environment and programming language for statistical computing, analysis and graphics that is supported by the R Foundation for Statistical Computing and is widely used by scientists from different research fields all over the world. The core capabilities of $\mathrm{R}$ are extended through specialized user-created packages, which allow specialized statistical techniques and are often specifically tailored to the demands of a certain research field. A set of packages are intended for analysis of geographical data in vector and raster forms. For instance, the raster package provides general raster data manipulation functions for creating, reading, manipulating, and writing raster data, that can be used to develop more specific functions.Raster $\mathrm{R}$ package can readgeoreferenced raster data in common formats (like GeoTIFF) and create specific raster objects that are input for analyses and manipulation.

The written $\mathrm{R}$ script, based on the functionality of raster package, gets a raster object as an input and returns a data frame (table) with two fields (columns) that keep the values of lags and corresponding autocovariances. This table can be used to build the plot (autocovariogram) with distance lags on $\mathrm{X}$ axis and autocovariances on $\mathrm{Y}$ axis, using plotting capabilities of R.

DEM's of each of 5 zones (Fig. 1) have been input to this script to obtain the tables and to build the respective autocovariograms. The results are shown in Fig. 2-4. 


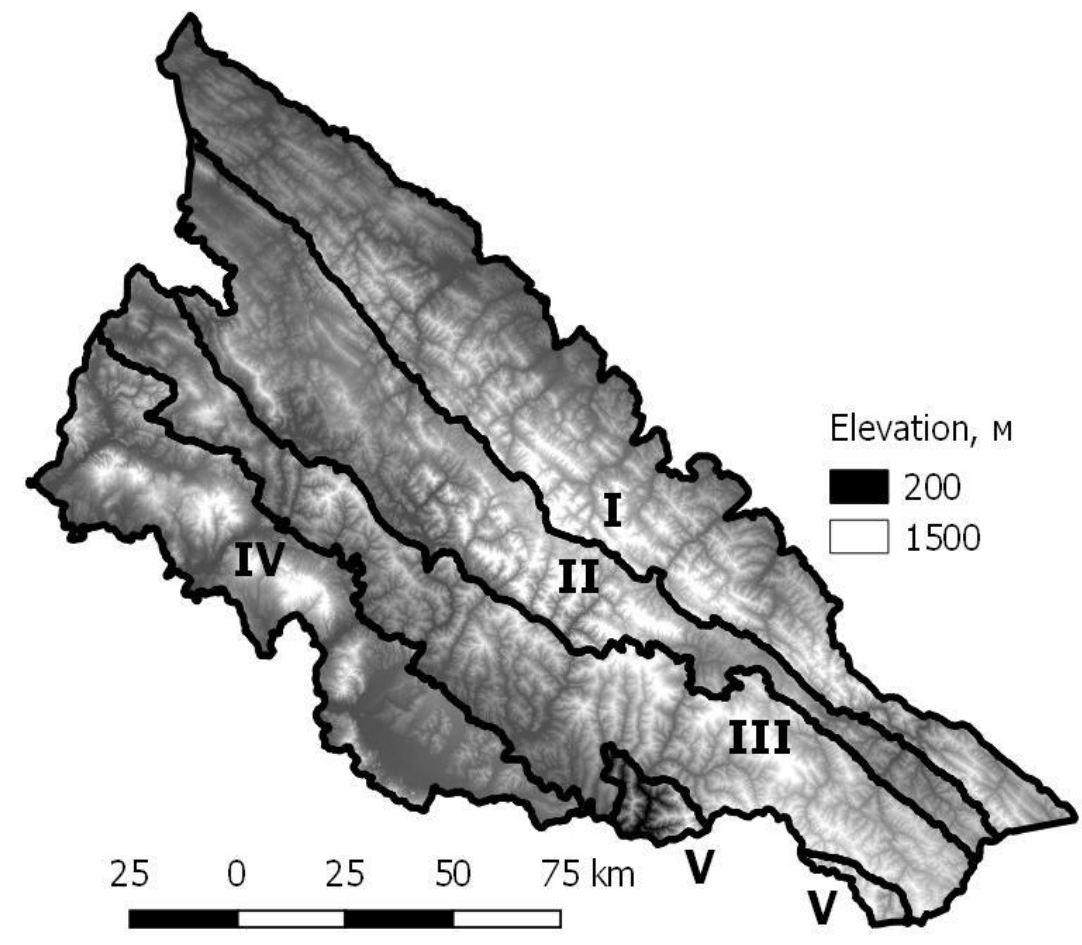

Fig. 1. Ukrainian Carpathians, their terrain and the main tectonic and geological zones delineated for the study:

I - External flysch cover (nappe) - Skybova zone;

II - External flysch cover - Krosno zone;

III - Internal flysch cover - Duklya, Porkulets, Chornohora and Polonynskanappes;

IV - Vyhorlat-Hutyn volcanic range and adjacent valleys;

V - Alpine crystal Maramures massif.
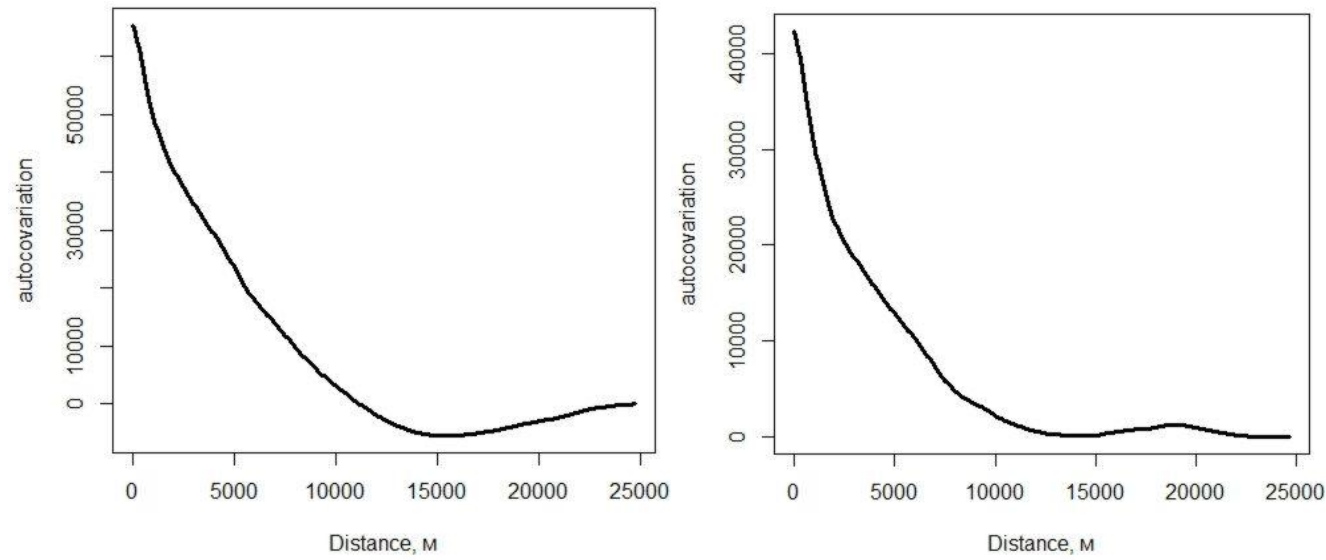

Fig. 2. Autocovariograms for zones 1 (left) and 2 (right), see Fig. 1. 

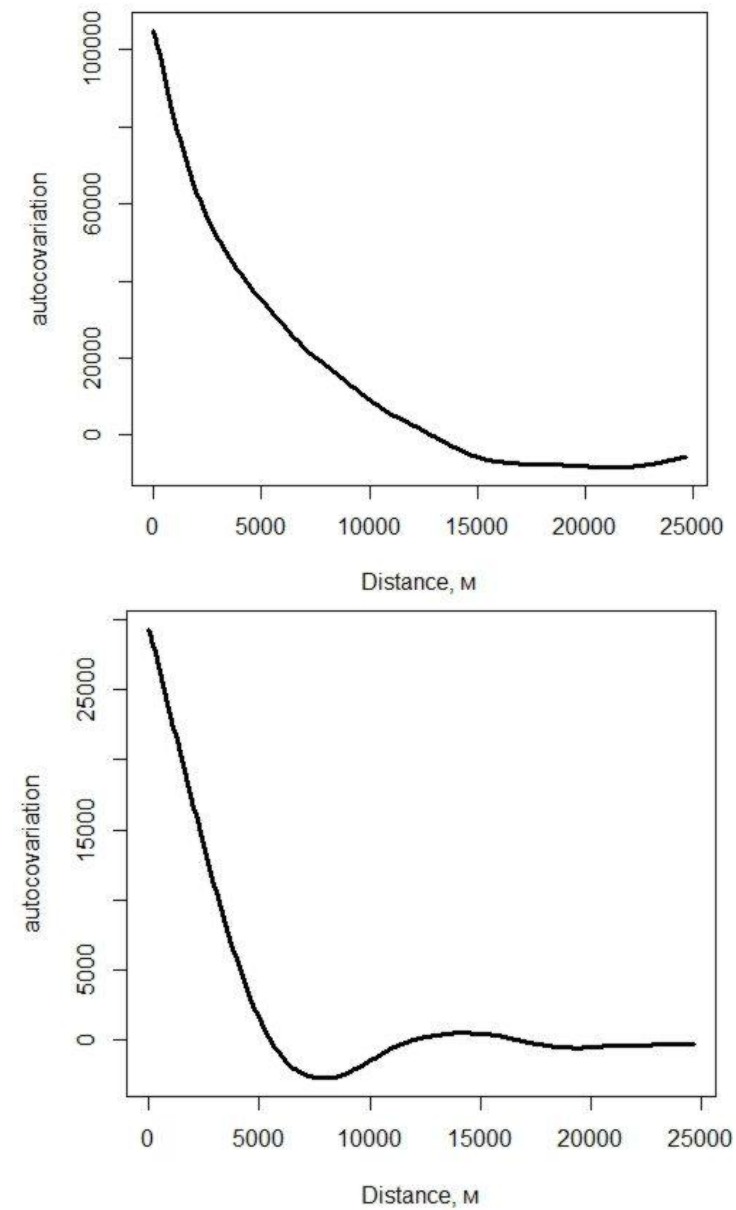

Fig. 3. Autocovariograms for zones 3 (left) and 4 (right), see Fig. 1.

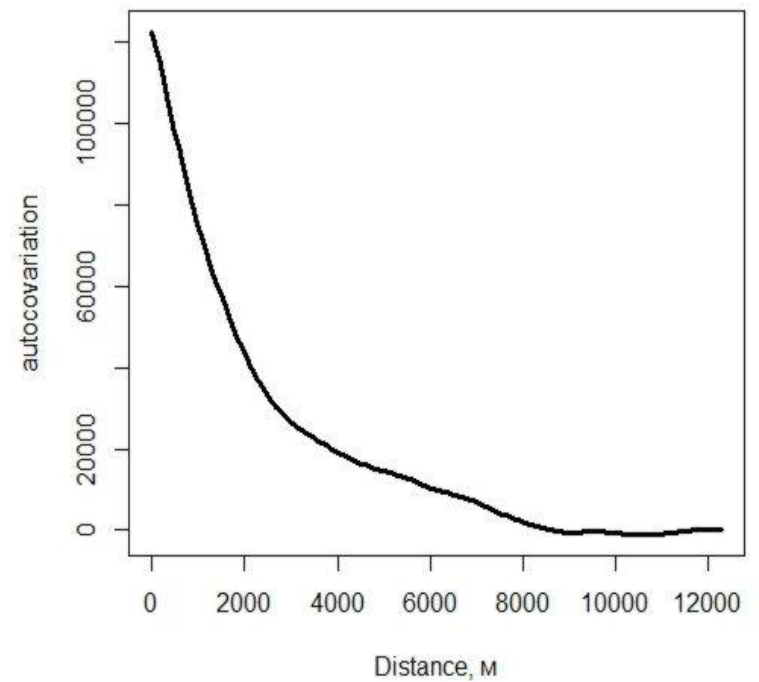

Fig. 4. Autocovariogram for zone 5, see Fig. 1. 
For zones 1-4 maximal lag for autocovariorgam has been set to $25 \mathrm{~km}$, and for zone 5 - to $12.5 \mathrm{~km}$ (due to its small extent and impossibility to calculate autocovariogram for large lags).

The general form of every autocovariogram looks similar - large initial values of autocovariance drop with distance till they reach close to 0 plateau at some range. Yet, the closer analysis can reveal some significant differences in detail. Firstly, the initial values and values at small lags differ a lot between them (as is noticeable by different default scales on Y axes on different plots). For zones 3 and 5 they are the highest, exceeding $100000 \mathrm{~m}^{2}$, for zones 1 and 2 - moderate, and the smallest for zone 4 . The pattern characteristicof periodicity is most pronounced for zones 4 and 1, slightly noticeable for zone 2, and absent for the zones 3 and 5. The lengths of spatial cycles also vary a lot. This length can be estimated as double the distance to the dip on the graph. For zone 1 (Fig. 2, left) it is approximately $30 \mathrm{~km}$ (the typical distance between river valleys crossing the mountain ranges). For zone 4 (Fig. 3, right) it is $12-15 \mathrm{~km}$, which is a typical distance between volcanic outlier hills - the characteristic terrain forms of this zone. Another feature of autocovariogram is a range at which values approach 0 , which is another indicator of local terrain scale. It is $7 \mathrm{~km}$ for zone $4,9 \mathrm{~km}$ for zone $5,12 \mathrm{~km}$ for zone 2, and $15 \mathrm{~km}$ for zones 1 and 3 . The general parameters and features of autocovariograms for different zones are shown on Table.

Features of autocovariograms for main tectonic and geological zones of Ukrainian Carpathians

\begin{tabular}{|c|r|r|l|}
\hline $\begin{array}{c}\text { Zone no. } \\
\text { (see Fig. 1) }\end{array}$ & $\begin{array}{c}\text { Initial value } \\
(\text { at lag 70 m) }\end{array}$ & Range $(\mathrm{km})$ & \multicolumn{1}{|c|}{ Periodicity } \\
\hline 1 & 65400 & 15 & Strong, $30 \mathrm{~km}$ \\
\hline 2 & 42400 & 12 & Slight, $22 \mathrm{~km}$ \\
\hline 3 & 105000 & 15 & No \\
\hline 4 & 29300 & 7 & Strong, $14 \mathrm{~km}$ \\
\hline 5 & 123000 & 9 & No \\
\hline
\end{tabular}

It can be noticed that most elevated part of the mountains with large ranges and massifs (zones 3 and 5) is characterized by the largest initial autocovariance values and the lack of periodicity. Still, there is a difference between these zones in that the autocovariogram for zone 3 has much higher range than that of zone 5. These two zones have different genesis and geological structure; the zone 3 consists of sedimentary rocks, and zone 5 - of igneous rocks. The latter zone has thus "alpine" look with more sharp relief forms, which is reflected in very sharp initial decline in its autocovariogram.

In general, parameters of autocovariogram can be indicative of tectonic structure and processes in the area, the genesis and composition of rocks (igneous, metamorphic or sedimentary), the dominant morphodynamic processes. Autocovariogram analysis of DEM can be used for the purposes of objective morphometric regionalization, the indication of unobvious tectonic and geologic structures, the estimation of the risks ofthe manifestation of dangerous and deleterious exogenousprocesses. 
The detailed interpretation of autocovariogram shapes, the relationships between features and parameters of autocovariograms and relief characteristics like its genesis, age and dynamics deserve further studies.

\section{REFERENCES}

1. Enzmann R. D. (1966). Introduction to the Section on Signatures, in Planetology and Space Mission Planning. Ann. New York Acad. Sci.,V. 140, Article 2, 154156.

2. Franklin J. (1995). Predictive vegetation mapping: geographic modelling of biospatial patterns in relation to environmental gradients. Progress in Physical Geography, 19(4), 494-519.

3. Guisan A., Zimmermann N. (2000). Predictive habitat distribution models in ecology. Ecological Modelling, 135, 147-186.

4. Jarvis A., Reuter H. I., Nelson A., Guevara E. (2008). Hole-filled seamless SRTM data v4. International Centre for Tropical Agriculture (CIAT). Retrieved from http://srtm.csi.cgiar.org.

5. Mitasova H. J., Hofierka M., Zlocha R., Iverson L. (1996). Modeling topographic potential for erosion and deposition using GIS. Int. J. of Geogr. Information Science, 10(5), 629-641.

6. Mkrtchian A. (2016). Annual precipitation data processing and interpolation for the weather stations of Western Ukraine. Proceedings of GeoMLA, Geostatistics and Machine Learning, Application in Climate and Environmental Sciences. Belgrade : Faculty of Civil Engineering, University, 61- 66.

7. Mkrtchian A. (2013). The relations between land surface morphometry and spectral characteristics of ecosystems in the Ukrainian Carpathians. Ekológia,Vol. 32, No. 1, 87-94.

8. Mkrtchian O., Shuber P. (2014). Analis zviazkiv mizh richnymy normamy kilkosti opadiv ta morphometrychnymy pokaznykamy relief dlia meteostanciy zahodu Ukrayiny [Analysis of relationships between annual precipitation norms and terrain attributes for the meteorological stations in Western Ukraine] Scientific Visnyk of Chernivtsi University. Ser. geogr.,724-725, 38-42.

9. Moore I.D., Gessler P. E., Nielsen G. A., Peterson G. A. (1993). Soil attribute prediction using terrain analysis. Soil Science Society of America Journal, 57, 443-452.

10.Pike R. J. (1988). The geometric signature: quantifying landslide terrain types from digital elevation models. Mathematical Geology, Vol. 20, No. 5, 491-511.

11.Pike R. J. (1995). Geomorphometry - progress, practice, and prospect. Z. Geomorph. Suppl.-Bd, 101, 221-238.

12.Shary P.A., Sharaya, L.S., Mitusov, A.V. (2002). Fundamental quantitative methods of land surface analysis. Geoderma, 107, 1-32.

13.Tobler W. A (1970). computer movie simulating urban growth in the Detroit region. Economic Geography, 46 (Supplement). 234-240.

14.Tobler W. (1967). Of Maps and Matrices. Journal of Regional Science, 7, 27580 . 


\title{
АНАЛІЗ МОРФОЛОГІЇ РЕЛЬЕФУ УКРАЇНСЬКИХ КАРПАТ МЕТОДОМ ПОБУДОВИ АВТОКОВАРІОГРАМ
}

\author{
Олександр Мкртчян \\ Львівський національний університет імені Івана Франка, \\ вул. П. Дорошенка 41, 79007, Львів, Україна, \\ alemkrt@gmail.com
}

\begin{abstract}
Кількісний морфометричний аналіз рельєфу, як новий перспективний напрям досліджень, вирішує низку важливих завдань. Одним з них є кількісна характеристика форм і типів рельєфу, що дає змогу побудувати їхні морфометричні сигнатури, за якими можна об’єктивно виокремити ці форми й типи, використовуючи автоматизовані методи.Завдання можна вирішити шляхом аналізу автоковаріаційної/автокореляційної структури топографічної поверхні.

В ході даного дослідження виконано обрахунок автоковаріограм для топографічних поверхонь п'ятьох зон в Українських Карпатах, виокремлених за ознакою тектонічної та геологічної будови, а також аналіз цих автоковаріограм. 3 цією метою використано спеціально створений скрипт мовою R. Завдяки скрипту проаналізовано фрагмент цифрової моделі рельєфу (SRTM Version 4.1) у межах кожної зони та розроблено відповідні таблиці з двома полями, які містять значення відстаней (лагів) та відповідних автоковаріацій. На основі цих таблиць графічними засобами $\mathrm{R}$ побудовано графіки автоковаріограми.

Тоді як загальний вигляд усіх трьох автоковаріограм є подібним, їхній детальніший аналіз виявив деякі помітні відмінності між ними. Загалом автоковаріограми для п'ятьох зон відрізняються між собою первинними значеннями, наявністю чи відсутністю періодичності поверхні рельєфу (iі індикують виражені локальні мінімуми на автоковаріограмі) та відстанню, на якій значення наближаються до нуля. Загалом риси та параметри автоковаріограми можуть вказувати на тектонічну структуру та процеси, генезис та склад поверхневих геологічних відкладів та домінуючі морфодинамічні процеси.

Ключові слова: геоморфометрія, автоковаріограма, мова R, цифрова модель рельєфу, Українські Карпати.
\end{abstract}

